\title{
Inequalities in Access to Medicines for Chronic Diseases in Different Regions of Brazil: A Population-Based Study.
}

\author{
Vanessa Miranda ( $\sim$ vanessairi@gmail.com ) \\ Antônio Augusto Schäfer \\ Southern Santa Catarina University: Universidade do Extremo Sul Catarinense \\ Cristiane Damiani Tomasi \\ Universidade do Extremo Sul Catarinense \\ Jacks Soratto \\ Universidade do Extremo Sul Catarinense \\ Fernanda de Oliveira Meller \\ Unesc: Universidade do Extremo Sul Catarinense \\ Marysabel Pinto Telis Silveira \\ Federal University of Pelotas: Universidade Federal de Pelotas
}

Southern Santa Catarina University: Universidade do Extremo Sul Catarinense https://orcid.org/0000-0002-9156-5036

Research

Keywords: Pharmaceutical Preparations, Pharmacoepidemiology, health inequalities, Cross-sectional Studies, diabetes, hypertension

Posted Date: November 10th, 2020

DOI: https://doi.org/10.21203/rs.3.rs-102595/v1

License: (c) (1) This work is licensed under a Creative Commons Attribution 4.0 International License. Read Full License 


\section{Abstract}

Objective

To analyze the economic and regional inequalities in access to medicines for diabetes and hypertension among the adult population in Brazil.

Methods

This was a cross-sectional study with adults aged 18 and over from the VIGITEL study conducted in 2019 in all Brazilian regions. Nonaccess to antidiabetic and antihypertensive drugs was assessed according to education and housing macro-region. The slope index of inequality (SII) was used to analyze the absolute inequalities.

Results

The total number of individuals interviewed was 52,443 . Approximately $10.0 \%$ of people with diabetes and/or hypertension reported not having access to drug treatment. For antihypertensive drugs, the main means of obtaining it in all regions was the private pharmacy, and for antidiabetics, the North had greater access through private pharmacies, while the Northeast, Southeast and South had greater access through public setor. Inequalities were found in the lack of access to medicines according to the region of residence, mainly for the North region.

Conclusion

The lack of access to medicines showed regional disparities, mainly in the most economically vulnerable regions.

\section{Background}

Brazil continues in a growing process of epidemiological transition, with an increase in the life expectancy of the population in recent decades, and a complex scenario of overlapping health problems can be observed, which is affected by the emergence of communicable diseases and an increase in chronic noncommunicable diseases (NCD) ${ }^{1,2}$, affecting even more vulnerable groups, with low education and lower income ${ }^{3}$.

In 2015, the United Nations (UN) set 17 Sustainable Development Goals (SDGs) to be achieved by 2030, with among its goals to reduce premature NCD mortality by one third through adequate prevention and treatment ${ }^{4}$. Model data predictors of mortality for the period 2000 to 2033 indicate that diseases of the circulatory system, including diabetes and hypertension, will continue to occupy the first place within diseases of the circulatory system ${ }^{5}$, which will cause increasing demand for the need to provide access to diagnosis and adequate treatment for the population ${ }^{6}$.

In low- and middle-income countries, adults face almost twice the risk of death from NCDs than those from high-income countries ${ }^{5}$. In Brazil, in $2013,72.6 \%$ of deaths were due to NCDs, and cardiovascular diseases were the most frequent, representing $29.7 \%$ of deaths, followed by neoplasms $(16.8 \%)$, chronic respiratory diseases $(5.9 \%)$ and diabetes $(5.1 \%)$. These four diseases accounted for $85 \%$ of deaths from $\mathrm{CNCD}^{6}$.

To guarantee prevention and adequate treatment, it is necessary for the population to have access to health services and technologies, including medicines. Access to basic and essential medicines for all individuals is a priority in current health policies, in addition to being a fundamental right, consecrated and recognized worldwide 7,8 .

Given the importance of universal access to medicines for the control of NCDs, as well as the identification of disparities in access to this treatment, the objective of this article is to analyze the economic and regional inequalities in access to medicines for diabetic and hypertensive patients among the adult population of Brazil.

\section{Methods}

A cross-sectional population-based study was carried out with Brazilian adults aged 18 years or older. Data from the Surveillance of Risk and Protection Factors for Chronic Diseases by Telephone Survey (VIGITEL) survey conducted in 2019 were used. VIGITEL is held 
annually in all Brazilian capitals and the Federal District and aims to monitor the frequency and the distribution of the main determinants of chronic noncommunicable diseases (NCDs) ${ }^{9}$.

For the selection of individuals, probabilistic samples were taken of adults living in households with at least one fixed telephone line. For the calculation of risk factor estimates, a 95\% confidence coefficient and a maximum error of $2 \mathrm{pp}$ were considered. For specific estimates, according to sex, 3 pp of maximum error was considered. The sample selection was carried out in two stages. In the first, at least 5,000 telephone lines per city were drawn, systematically and stratified by postal code (CEP). Afterwards, the drawn lines were resorted and divided into replicas of 200 lines, which had the same proportion of lines per CEP as the original register.

Initially, 197,600 telephone lines were drawn, and to reach the minimum number of 2,000 interviews per capital, 36 replicates were used per city, with a range of 30 to 56 replicates, depending on the state. In the second stage, one of the eligible adults residing in the selected household was selected. More details about the research can be found in the published report ${ }^{9}$.

The following lines were not eligible for the survey: they corresponded to companies; they no longer existed or were out of service; in addition to the lines that did not respond to six attempts at calls made on different days and times, including Saturdays and Sundays and night periods, and which probably corresponded to closed households.

The applied questions addressed sociodemographic characteristics and information on health status and various risk factors for NCDs. The dependent variables analyzed in this study were the report of diabetes or hypertension previously diagnosed by a doctor, the use of drugs (for those who had these diseases), the source for obtaining the drugs and the lack of access.

The independent variables were age in full years, according to four categories (18-24; $25-39 ; 40-59 ; \geq 60)$, sex (male; female), self-reported skin color (white; black; brown), education in years (none; $1-4 ; 5-8 ; 9-11 ; \geq 12$ ) and region of residence (North; Northeast; Midwest; Southeast; South).

Data analysis was performed using the STATA $®$ statistical program, version 15.0 , and the weightings related to the complex sample design were considered using the Rake method ${ }^{10}$, which corrects the estimates and provides reliable information for the adult population with landline in each municipality, since the use of this weight equates the sociodemographic composition estimated from the VIGITEL sample in each city to the sociodemographic composition estimated for the total adult population of the city same town.

The effect of the sample design was considered for all analyses, using the set of svy commands, specific for the analysis of surveys based on complex samples of the statistical program Stata 15.0. The sample was described in relation to the independent variables, and the prevalence of outcomes (hypertension and diabetes) was calculated with the respective confidence intervals using Pearson's Chisquare test, using the significance level of 0.05 .

In addition, analyses stratified by education (wealth proxy) and by region of residence were performed to describe the lack of access to medicines for diabetes and hypertension. To identify possible inequalities, the slope index (SII) was used ${ }^{11}$. The SII presents the absolute difference in percentage points (ranging from -100 to $+100 \%$ ) between the extremes, for example, the richest and the poorest quintile, using a logistic regression model. A significance level of 0.05 was considered. To better illustrate these differences between the subgroups, equiplot graphics were used (Figure 2).

The VIGITEL research project was approved by the National Commission for Ethics in Research for Human Beings of the Ministry of Health (CAAE: 65610017.1.0000.0008). The Free and Informed Consent was obtained verbally at the time of the telephone call that was carried out by a central office and had all the interviews recorded aiming at data quality control.

\section{Results}

Of the total sample of 52,443 individuals, $7.5 \%(95 \% \mathrm{Cl} 7.0 ; 7.8)$ reported having diabetes; of these, $84.0 \%$ were using oral diabetes medications, and $20.4 \%$ were using insulin. Of the $24.5 \%(95 \% \mathrm{Cl} 23.8 ; 25.3)$ who reported having hypertension, $83.4 \%$ reported being on medication. On the other hand, approximately $10.0 \%$ of people with diabetes and/or hypertension reported a lack of access to these drugs.

Table 1 shows the description of the interviewed sample and the prevalence of lack of access to medicines for diabetes and hypertension according to sociodemographic characteristics. It was observed that the lack of access decreases with increasing age for both drugs. Furthermore, the lack of access to antihypertensive drugs was greater in those individuals with less education ( 1 - 4 and $9-11$ years). 
Regarding the characteristics of individuals according to chronic diseases, a higher prevalence of hypertension was observed among female individuals, with a positive trend with age. On the other hand, the prevalence tends to decrease with the increase in schooling. The region with the highest prevalence of hypertensive patients was the Midwest, followed by the Southeast. Regarding individuals with diabetes, there were no differences between genders, and there was a trend of increasing prevalence with advancing age. For the education variable, an inversely proportional trend was observed. In addition, differences were found in the prevalence of diabetes between regions, with the Southeast being the one with the highest proportion (data not shown in the table).

Regarding the form of access to medicines for hypertension and diabetes according to the region of residence, it was observed that among antihypertensive drugs, the main means of obtaining in all regions was through the private pharmacy, through purchase, being greater in the Midwest (52.1\%) and North (51.2\%) regions. For antidiabetic drugs, no standard of achievement was found. The North region had greater access through private pharmacies (41.3\%), while the Northeast, Southeast and South regions had greater access through SUS (34.7\%, $48.3 \%$ and $41.7 \%$, respectively) (Figure 1 ).

According to the assessed inequality index (Table 2), inequalities were found when assessing the lack of access to medicines according to the region of residence, pointing out that the lack of access for anti-hypertensive and anti-diabetic drugs occurs in greater magnitude in the residents of the North region. For medicines for hypertension, residents in the Northeast have less access than residents in the South and for antidiabetics less access than those in the South (Figure 2).

About education, the indices suggest that individuals with no education have, on average, less access to antihypertensive drugs when compared to those with more education; however, the estimates were not significant (Table 2).

\section{Discussion}

Access to medicines is part of the right to health, which in turn must be promoted through the adoption of public policies and, in some cases, legislative mechanisms to provide their guarantee ${ }^{12,13}$. Nevertheless, there is an inequity in this guarantee, which reinforces the need to strengthen the Unified Health System for the free supply of medicines to reduce inequalities ${ }^{14}$.

Among the individuals interviewed, $84.0 \%$ of diabetic patients and $83.4 \%$ of hypertensive patients were using drug treatment. It is known that the control of both chronic diseases is based on a series of precautions, which involve nutritional changes, physical activity and control of some risk factors ${ }^{15,16}$. However, drug treatment becomes the most effective way to control and prevent complications of these morbidities, as adherence to lifestyle changes is always less than adherence to treatment ${ }^{17}$. However, for this treatment to be effective, it is necessary that the user has access to it ${ }^{18}$.

A study conducted with data from the 2011 VIGITEL survey showed a lower prevalence of medication use among diabetic and hypertensive patients, with $78.2 \%$ and $72.0 \%$, respectively, compared to the present article ${ }^{19}$. The National Health Survey (2013) showed that $80.2 \%$ and $81.4 \%$ used drugs to control diabetes and hypertension, respectively ${ }^{20}$. These results suggest a progression in the use of medications for these two chronic conditions. The increase in the use of medicines for these diseases may also reflect less healthy behavior, which leads to an increase in the prevalence of hypertension and diabetes, leading to an increase in the population in need of these medicines.

The general lack of access to medicines for diabetes and hypertension was approximately $10.0 \%$. Although the findings indicate that the constitutional right of health may be compromised by a portion of the investigated participants, it should be noted that access to antihypertensives and antidiabetics in Brazil can be considered, and this is due to a series of public policies that have been adopted to guarantee universal and free access to medicines ${ }^{21}$.

In 1998, Brazil instituted the National Medicines Policy ${ }^{8}$, adopting, among other guidelines, the National List of Essential Medicines ${ }^{12}$. Subsequently, the generic medicine policy was also implemented, whose objective was to expand access to medicines with guaranteed quality and at a more affordable price for the population, and in 2004, the Popular Pharmacy Program (PFP) was created within the scope of the System Unified Health System (SUS) ${ }^{22}$. PFP emerged with the aim of expanding access to medicines to the entire population, aiming to prevent treatment abandonment, especially in low-income individuals who have difficulties acquiring the necessary medicines in private pharmacies ${ }^{23}$. In 2011, the program was reformulated to further increase the coverage of pharmaceutical assistance and promote comprehensive health care, changing its name to "Health is priceless", in which medicines for the treatment of diabetes, hypertension and asthma passed to be provided free of charge ${ }^{24}$. 
When assessing access to different sources of medication, the main means of obtaining antihypertensive drugs in all regions was the private pharmacy. This finding may reflect a series of barriers that still exist, such as difficulty in accessing the consultation for renewing the prescription for withdrawing medications, lack of knowledge about the list of medications available for free, prejudice against free medications provided by the government, and geographical limitations, among others ${ }^{3,25}$. For diabetes medications (oral and insulin), it was observed that the North, Northeast, and Midwest regions had private pharmacies as the main means of obtaining them, suggesting regional disparities in access.

The same was observed in the National Survey on Access, Use and Promotion of Rational Use of Medicines ${ }^{26}$, which pointed to statistically significant differences in access to essential medicines between regions of the country, as well as according to the type of medicine. A study carried out based on the VIGITEL survey (2011) showed that people who live in the capitals of Brazilian regions with less economic development and a larger socially vulnerable population are also those who most needed to make direct disbursements to access treatment for hypertension and diabetes ${ }^{19}$, pointing out how unequal health care is in a country with continental dimensions such as Brazil.

This study highlights the difficulties of obtaining medication in the North region, which clearly demonstrates geographical inequalities when compared with the South region existing in the field of health. Accessing medication in the referred region is a challenge for the user, and for the management of services to provide it, adding to this, it also has a more peculiar condition of other regions, such as the geography of the Amazon territory. The geographical limitations that constitute barriers to access to health services can make it difficult to acquire epidemiological information and medications from certain populations, causing health problems to often be solved with the use of allopathic medication ${ }^{27}$.

This support for inequality as a geographical difficulty in accessing medication is further strengthened when analyzing some of the different spaces for dispensing medications, such as the Family Health Strategies (FHS) ${ }^{28}$. While the North region has family health coverage of more than $63.0 \%$, the Southeast region has less than $54.0 \%{ }^{29}$, which converges with the hypothesis that it is not enough to guarantee dispensing structures for effective access to medication, if the ability of users or patients to get it is not taken into account, as well as the hypothesis that the distribution of health services health is not proportional to the distribution of demands ${ }^{28}$.

Among the limitations of the study, since it is self-reported information, the memory bias of the interviewees stands out, possible differences in the understanding of some issues and the selection bias, since the survey did not include individuals living in households without a landline.

\section{Conclusion}

The results obtained by this population survey expand knowledge about access to medicines and highlight the growth and expansion of pharmaceutical assistance, with the free availability of medicines for diabetes and hypertension present in UBS and pharmacies affiliated with PFP. On the other hand, the results also point out that there is still a portion of the population without access to these essential medicines, especially in the most economically vulnerable regions, evidencing the existence of regional disparities and, in this way, contributing to the direction of existing public health policies.

\section{Declarations}

Ethical approval: the National Commission of Ethics in Research approved Vigitel 2019 for Human Beings of the Ministry of Health through CAAE: 65610017.1.0000.0008.

Consent for publication: Not applicable

\section{Availability of data and materials:}

All data are public and can be found on the official website of the study https://saude.gov.br/saude-de-a-z/vigitel

Conflict of interest: The authors declare that they have no conflict of interest.

Funding: There was no funding for the research.

Informed consent: Informed consent was obtained from all individual participants included in the study. 
V. I. A. Miranda, F. O. Meller and A. A. Schäfer participated in the analysis and interpretation of the data. F. O. Meller, A. A. Schäfer, M. P. T. Silveira, C. D. Tomasi, J. Soratto wrote the article, critically reviewed the intellectual content and approved the final version to be published. All authors are responsible for all aspects of the work in ensuring the accuracy and integrity of any part of the work.

Acknowledgements: Not applicable

\section{References}

1. Paim J, Travassos C, Almeida C, Bahia L, Macinko J. The Brazilian health system: history, advances, and challenges. The Lancet 2011; 377(9779): 1778-97. https://doi.org/10.1016/S0140-6736(11)60054-8

2. Schmidt MI, Duncan BB, e Silva GA, Menezes AM, Monteiro CA, Barreto SM, et al. Chronic non-communicable diseases in Brazil: burden and current challenges. The Lancet 2011;377(9781): 1949-61. https://doi.org/10.1016/S0140-6736(11)60135-9

3. Paniz VMV, Fassa AG, Facchini LA, Bertoldi AD, Piccini RX, Tomasi E, et al. Acesso a medicamentos de uso contínuo em adultos e idosos nas regiões Sul e Nordeste do Brasil. Cad. Saúde Pública 2008; 24( 2 ): 267-280. https://doi.org/10.1590/S0102$311 \times 2008000200005$

4. United Nations. Transforming Our World: The 2030 Agenda for Sustainable Development. Resolution Adopted by the General Assembly on 25 September 2015. New York: United Nations; 2015.

5. Silva JBS, Ramalho WM. Cenário epidemiológico do Brasil em 2033:uma prospecção sobre as próximas duas décadas - Rio de Janeiro : Fundação Oswaldo Cruz, 2015. 16 p.- (Textos para Discussão; n. 17)

6. Malta DC, Andrade SSC de A, Oliveira TP, Moura L de, Prado RR do, Souza M de FM de. Probabilidade de morte prematura por doenças crônicas não transmissíveis, Brasil e regiões, projeções para 2025. Rev Bras Epidemiol 2019; 22: e190030. https://doi.org/10.1590/1980-549720190030

7. Arrais PSD, Brito LL, Barreto ML, Coelho HLL. Prevalência e fatores determinantes do consumo de medicamentos no Município de Fortaleza, Ceará, Brasil. Cad. Saúde Pública 2005; 21(6 ): 1737-1746. https://doi.org/10.1590/S0102-311X2005000600021.

8. Brasil. Ministério da Saúde. Política Nacional de Medicamentos: informe técnico institucional. Brasília: Ministério da Saúde, 2000. http://bvsms.saude.gov.br/bvs/publicacoes/colec_progestores_livro7.pdf. Accessed 20 sept 2020.

9. Vigitel. Brasil 2019: vigilância de fatores de risco e proteção para doenças crônicas por inquérito telefônico: estimativas sobre frequência e distribuição sociodemográfica de fatores de risco e proteção para doenças crônicas nas capitais dos 26 estados brasileiros e no distrito federal em 2019. Ministério da Saúde (MS), Secretaria de Vigilância em Saúde, Departamento de Análise em Saúde e Vigilância de Doenças Não Transmissíveis. Brasília: MS; 2020. https://portalarquivos2.saude.gov.br/images/pdf/2019/julho/25/vigitel-brasil-2018.pdf. Accessed 20 sept 2020.

10. GRAHAM, K. Compensating for missing survey data. Michigan: Ann Arbor, 1983. Survey Research Center Institute for Social Research The University of Michigan.

11. Barros AJD, Victora CG. Measuring Coverage in MNCH: Determining and Interpreting Inequalities in Coverage of Maternal, Newborn, and Child Health Interventions. PLoS Med 2013; 10(5): e1001390. https://doi.org/10.1371/journal.pmed.1001390

12. Portela AS, Leal AAF, Werner RPB, Simões MOS, Medeiros ACD. Políticas públicas de medicamentos: trajetória e desafios. Rev ciênc farm básica apl. 2010;31(1): 09-14.

13. Catanheide ID, Lisboa ES, Souza LEPF. Características da judicialização do acesso a medicamentos no Brasil: uma revisão sistemática. Physis 2016; 26( 4 ): 1335-1356. http://dx.doi.org/10.1590/s0103-73312016000400014.

14. Drummond ED, Simões TC, Andrade FBd. Acesso da população brasileira adulta a medicamentos prescritos. Rev. bras. epidemiol. 2018; 21: e180007. https://doi.org/10.1590/1980-549720180007.

15. Nicolucci A, Greenfield S, Mattke S. Selecting indicators for the quality of diabetes care at the health systems level in OECD countries. Int J Qual Health Care. 2006;18 Suppl 1:26-30.

16. Brasil. Ministério da Saúde. Secretaria de Atenção à Saúde. Departamento de Atenção Básica. Estratégias para o cuidado da pessoa com doença crônica: diabetes mellitus / Ministério da Saúde, Secretaria de Atenção à Saúde, Departamento de Atenção Básica. Brasília: Ministério da Saúde, 2013. 160 p.: il. (Cadernos de Atenção Básica, n. 36). http://bvsms.saude.gov.br/bvs/publicacoes/estrategias_cuidado_pessoa_diabetes_mellitus_cab36.pdf. Accessed 20 sept 2020. 
17. Malachias M, Plavnik F, Machado C, Malta D, Scala L, Fuchs S. 7th Brazilian Guideline of Arterial Hypertension: Chapter 1 - Concept, Epidemiology and Primary Prevention. J Arquivos Brasileiros de Cardiologia. 2016;107:1-6.

18. Vieira FS. Possibilidades de contribuição do farmacêutico para a promoção da saúde. Ciênc. saúde coletiva. 2007; 12 ( 1 ): $213-220$. http://dx.doi.org/10.1590/S1413-81232007000100024

19. Costa KS, Francisco PMSB, Malta DC, Barros MBA. Fontes de obtenção de medicamentos para hipertensão e diabetes no Brasil: resultados de inquérito telefônico nas capitais brasileiras e no Distrito Federal, 2011. Cad. Saúde Pública. 2016, vol.32, n.2. http://dx.doi.org/10.1590/0102-311X00090014.

20. Monteiro CN, Lima MG, Szwarcwald CL, Bastos TF, Barros MBdA. Utilização de anti-hipertensivos e antidiabéticos no Brasil: análise das diferenças socioeconômicas. Pesquisa Nacional de Saúde 2013. Rev. bras. Epidemiol 2019; 22( Suppl 2): http://dx.doi.org/10.1590/1980-549720190014.supl.2.

21. Mengue SS, Bertoldi AD, Ramos LR, Farias MR, Oliveira MA, Tavares NUL, et al. Acesso e uso de medicamentos para hipertensão arterial no Brasil. Rev. Saúde Pública 2016; 50( Suppl 2 ): 8s. http://dx.doi.org/10.1590/s1518-8787.2016050006154.

22. Brasil. Ministério da Saúde. Programa Farmácia Popular do Brasil: manual básico. Brasília (DF); 2005. http://bvsms.saude.gov.br/bvs/publicacoes/PROGRAMA_FARMACIA_POPULAR.pdf. Accessed 20 May 2020.

23. Trevisan L, Junqueira LAP. Gestão em rede do SUS e a nova política de produção de medicamentos. Saude soc 2010; 19 ( 3 ): 638652. http://dx.doi.org/10.1590/S0104-12902010000300015.

24. Brasil. Ministério da Saúde. Secretaria de Ciência, Tecnologia e Insumos Estratégicos, Departamento de Assistência Farmacêutica e Insumos Estratégicos. Programa Farmácia Popular do Brasil: manual de informações às unidades credenciadas: sistema de copagamento. 2.ed. Brasília (DF); 2008.

https://livroaberto.ibict.br/bitstream/1/587/1/Programa\%20farmacia\%20popular\%20manual\%20sistema\%20copagamento_2ed.pdf. Accessed 20 May 2020.

25. Miranda VIA, Fassa AG, Meucci RD, Lutz BH. Use of the Brazilian People's Pharmacy Program by older adults. Rev. Saúde Pública 2016; 50: 13. https://doi.org/10.1590/S1518-8787.2016050006180.

26. Nascimento RCRMD, Álvares J, Guerra Junior AA, Gomes IC, Costa EA, Leite SN, et al. Availability of essential medicines in primary health care of the Brazilian Unified Health System. Rev. Saúde Pública 2017; 51( Suppl 2 ): 10s. http://dx.doi.org/10.11606/s15188787.2017051007062 .

27. Gama ASM, Fernandes TG, Parente RCP, Secoli SR. Inquérito de saúde em comunidades ribeirinhas do Amazonas, Brasil. Cad. Saúde Pública; 34( 2 ): e00002817. https://doi.org/10.1590/0102-311x00002817.

28. Andrade MV, Coelho AQ, Xavier Neto M, Carvalho LR, Atun R, Castro MC. Brazil's Family Health Strategy: factors associated with programme uptake and coverage expansion over 15 years (1998-2012). Health Policy Plan 2018;33(3):368-80. http://dx.doi.org/10.1093/heapol/czx189.

29. Neves RG, Flores TR, Duro SMS, Nunes BP, Tomasi E. Tendência temporal da cobertura da Estratégia Saúde da Família no Brasil, regiões e Unidades da Federação, 2006-2016. Epidemiol. Serv. Saúde 2018; 27( 3). https://doi.org/10.5123/s167949742018000300008.

\section{Tables}

Table 1. Sample characteristics and prevalence of lack of access to medicines for diabetes and hypertension. 


\begin{tabular}{|c|c|c|c|c|c|c|c|}
\hline \multirow[t]{2}{*}{ Variable } & \multirow{2}{*}{$\begin{array}{l}\text { Total sample } \\
\%\end{array}$} & \multicolumn{3}{|c|}{ Lack of access to diabetes medications } & \multicolumn{3}{|c|}{ Lack of access to medicines for hypertension } \\
\hline & & $\%$ & $95 \% \mathrm{Cl}$ & $P$ value & $\%$ & $95 \% \mathrm{Cl}$ & $P$ value \\
\hline Gender & & & & 0.177 & & & 0.601 \\
\hline Male & 46.0 & 11.0 & $8.3 ; 14.3$ & & 10.0 & $8.0 ; 12.3$ & \\
\hline Female & 54.0 & 8.7 & $7.1 ; 10.7$ & & 10.6 & $9.4 ; 11.9$ & \\
\hline Age (years) & & & & $0.025^{\mathrm{a}}$ & & & $<0.001^{\mathrm{a}}$ \\
\hline $18-24$ & 13.7 & 19.3 & $6.8 ; 43.9$ & & 17.7 & $5.9 ; 42.3$ & \\
\hline 25-39 & 33.4 & 16.1 & $9.3 ; 26.2$ & & 12.3 & $8.7 ; 17.0$ & \\
\hline $40-59$ & 34.6 & 10.5 & $7.8 ; 13.9$ & & 12.8 & $10.8 ; 15.2$ & \\
\hline 60 or more & 18.3 & 7.8 & $6.2 ; 9.7$ & & 7.6 & $6.7 ; 8.6$ & \\
\hline Ethnicity & & & & 0.115 & & & 0.357 \\
\hline White & 43.8 & 8.7 & $6.4 ; 11.6$ & & 9.7 & $8.1 ; 11.7$ & \\
\hline Black & 11.4 & 15.2 & $9.6 ; 23.3$ & & 9.9 & $7.4 ; 13.0$ & \\
\hline Brown & 44.8 & 10.3 & $7.9 ; 13.4$ & & 11.4 & $9.7 ; 13.4$ & \\
\hline Education (years) & & & & 0.279 & & & 0.037 \\
\hline none & 2.1 & 12.5 & $5.1 ; 27.3$ & & 8.1 & $5.7 ; 11.5$ & \\
\hline $1-4$ & 10.7 & 9.4 & $6.8 ; 12.8$ & & 11.3 & $8.7 ; 14.5$ & \\
\hline $5-8$ & 16.0 & 7.2 & $4.9 ; 10.3$ & & 12.0 & $9.6 ; 14.7$ & \\
\hline $9-11$ & 38.4 & 12.2 & $9.1 ; 16.1$ & & 10.7 & $8.9 ; 12.6$ & \\
\hline 12 or more & 32.8 & 8.7 & $6.0 ; 12.4$ & & 7.2 & $5.8 ; 9.0$ & \\
\hline Region of residence & & & & 0.188 & & & 0.060 \\
\hline North & 10.4 & 13.4 & $9.6 ; 18.3$ & & 12.5 & $10.2 ; 15.3$ & \\
\hline Northeast & 25.2 & 11.0 & $9.0 ; 13.3$ & & 12.1 & $10.7 ; 13.5$ & \\
\hline Midwest & 11.8 & 9.2 & $5.3 ; 15.4$ & & 10.2 & $7.9 ; 13.1$ & \\
\hline Southeast & 44.6 & 9.3 & $6.7 ; 12.6$ & & 9.7 & $7.8 ; 11.9$ & \\
\hline South & 8.0 & 5.6 & $3.5 ; 8.6$ & & 7.7 & $5.9 ; 9.9$ & \\
\hline
\end{tabular}

P-value: chi-square test for heterogeneity

a: $p$-value of the linear trend test

Table 2. Absolute inequality (Slope Index-SII) in the lack of access to medicines for hypertension and diabetes in relation to the education and region of residence of the studied Brazilians. Vigitel. 2019. 


\begin{tabular}{|lllllllllll|}
\hline \multicolumn{7}{|l|}{$\begin{array}{l}\text { Prevalence of lack of access } \\
\text { according to schooling }\end{array}$} \\
& none & $\mathbf{1} \mathbf{~ a ~} \mathbf{4}$ & $\mathbf{5} \mathbf{~ \mathbf { ~ }}$ & $\mathbf{9}$ a $\mathbf{1 1}$ & $\mathbf{1 2}$ or more & P value & SII & P value \\
\hline Antihypertensive & 8.2 & 11.3 & 12.0 & 10.7 & 7.2 & 0.037 & -3.6 & 0.056 \\
\hline Antidiabetic & 12.5 & 9.4 & 7.2 & 12.2 & 8.7 & 0.279 & 0.7 & 0.825 \\
\hline & Prevalence of lack of access by region of residence & & & \\
\hline Antihypertensive & 12.5 & 12.1 & 10.2 & 9.7 & 7.7 & 0.065 & -4.7 & 0.004 \\
\hline Antidiabetic & 13.5 & 11.0 & 9.2 & 9.3 & 5.6 & 0.188 & -5.4 & 0.020 \\
\hline
\end{tabular}

\section{Figures}

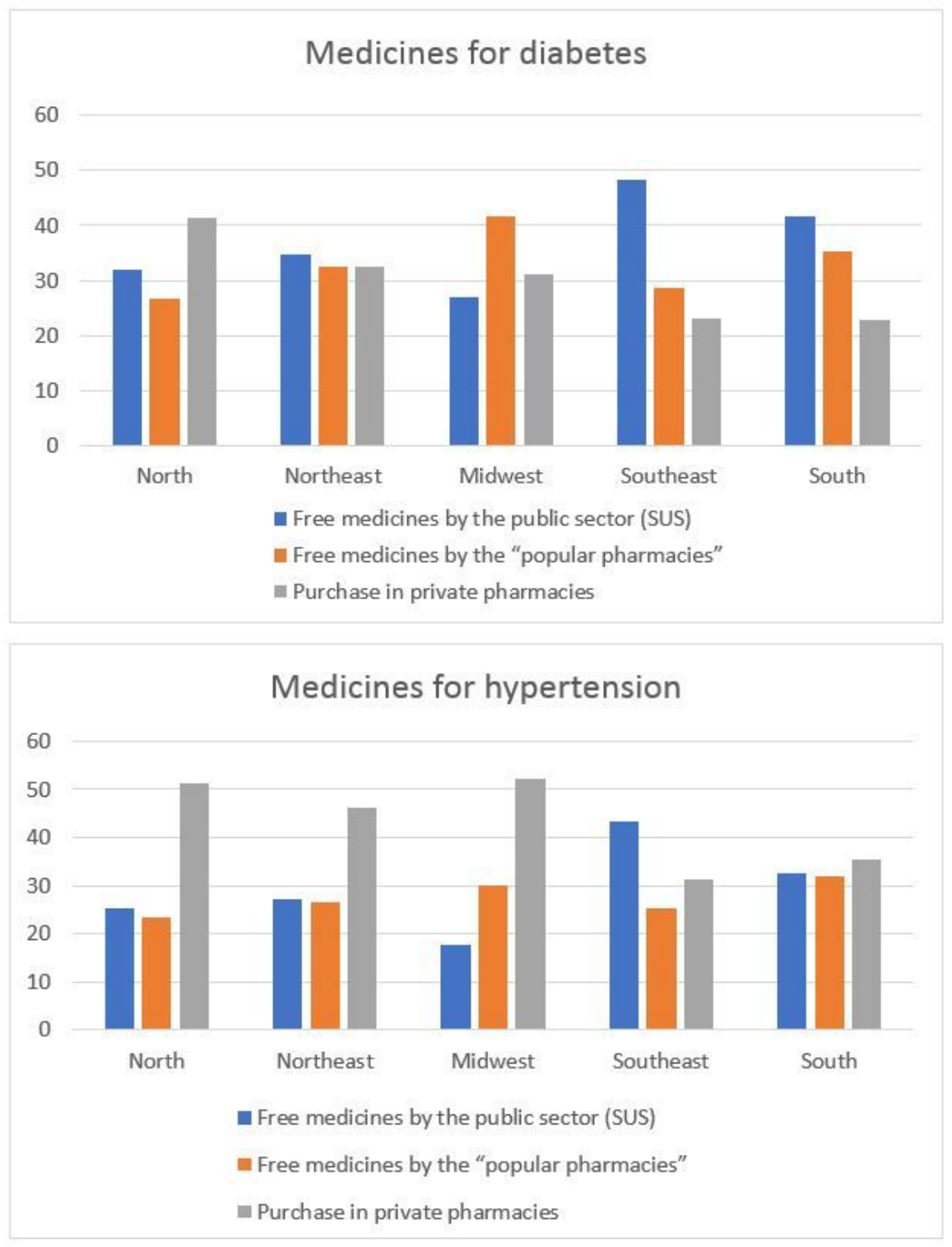

Figure 1

Form of access to medicines for hypertension and diabetes according to the region of residence of the Brazilians studied. Vigitel. 2019. 


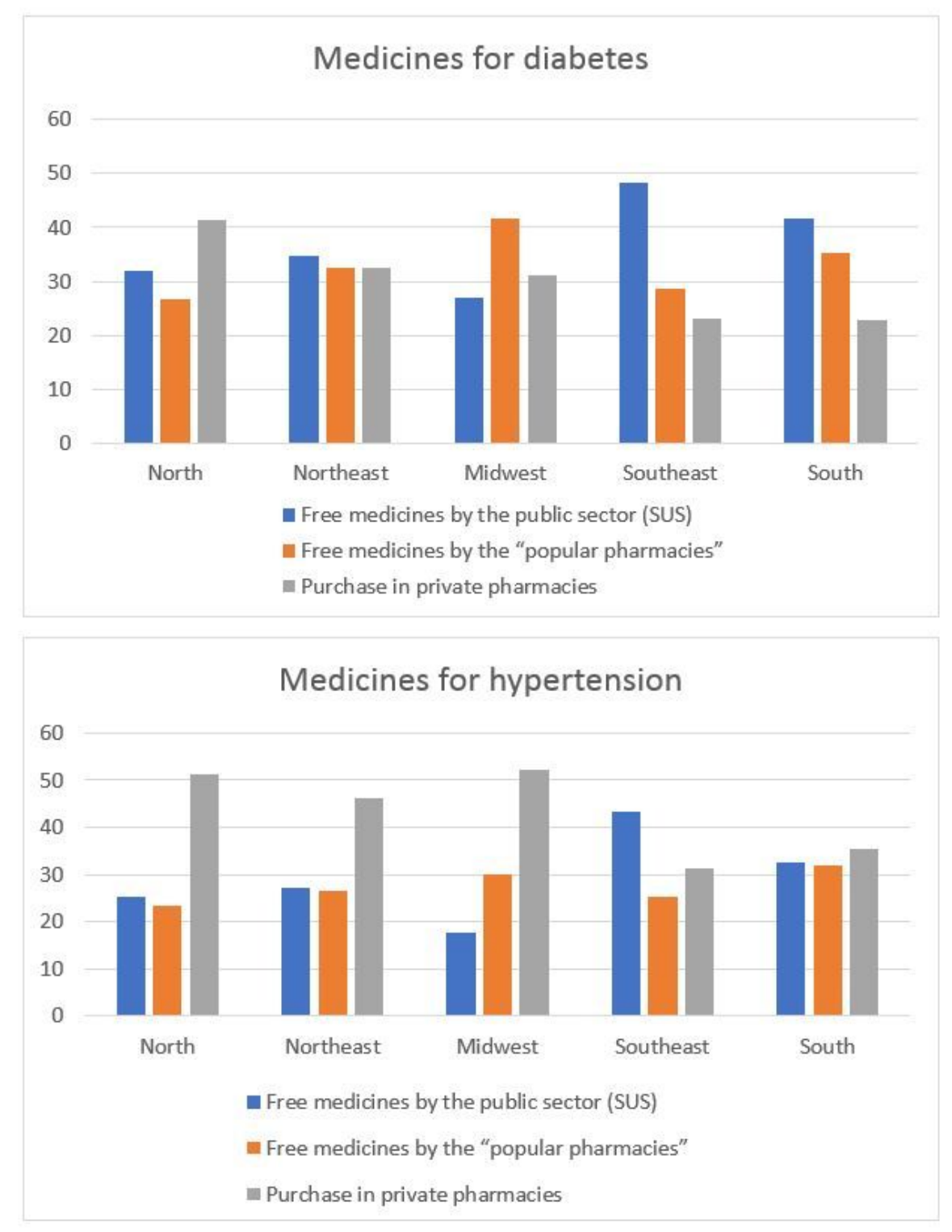

Figure 1

Form of access to medicines for hypertension and diabetes according to the region of residence of the Brazilians studied. Vigitel. 2019. 


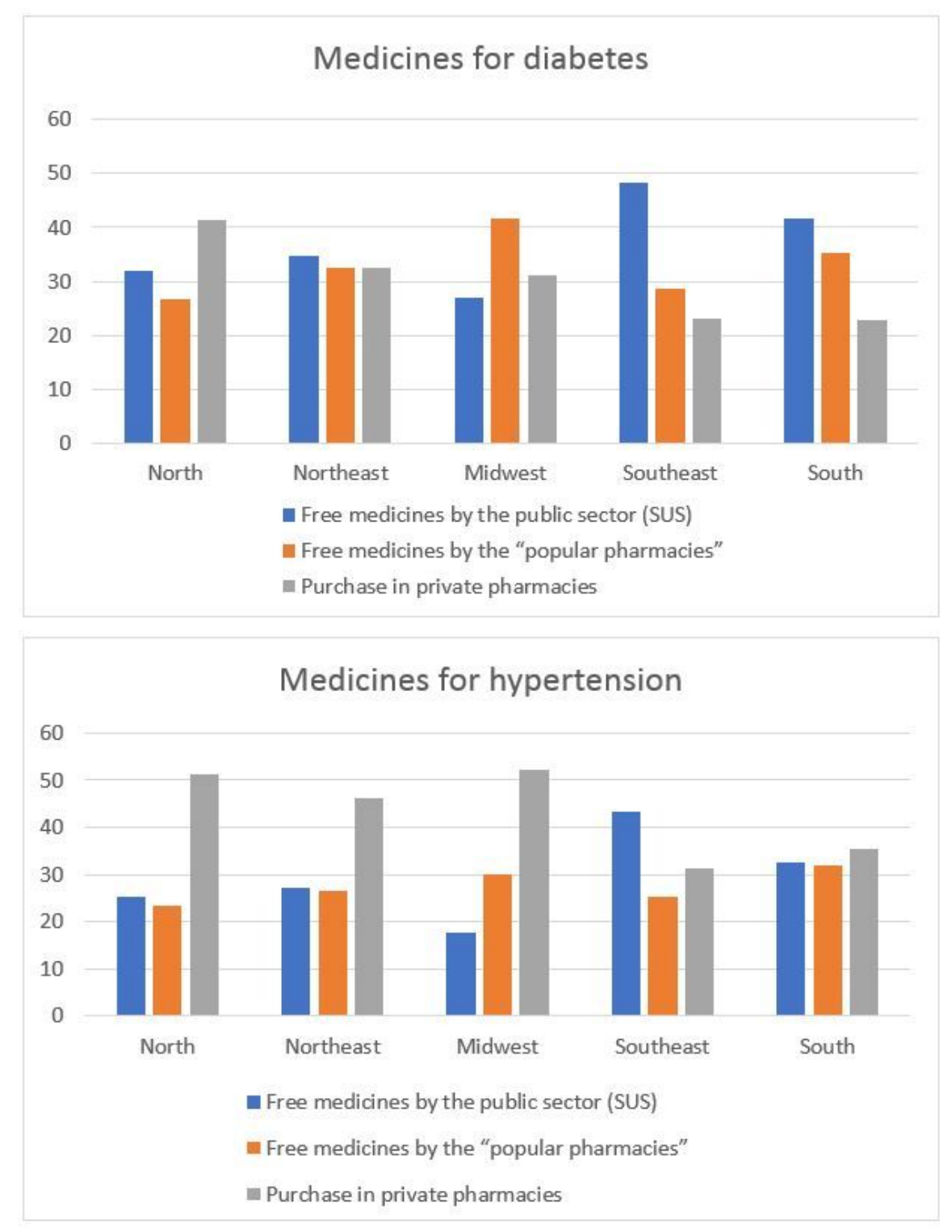

Figure 1

Form of access to medicines for hypertension and diabetes according to the region of residence of the Brazilians studied. Vigitel. 2019. 


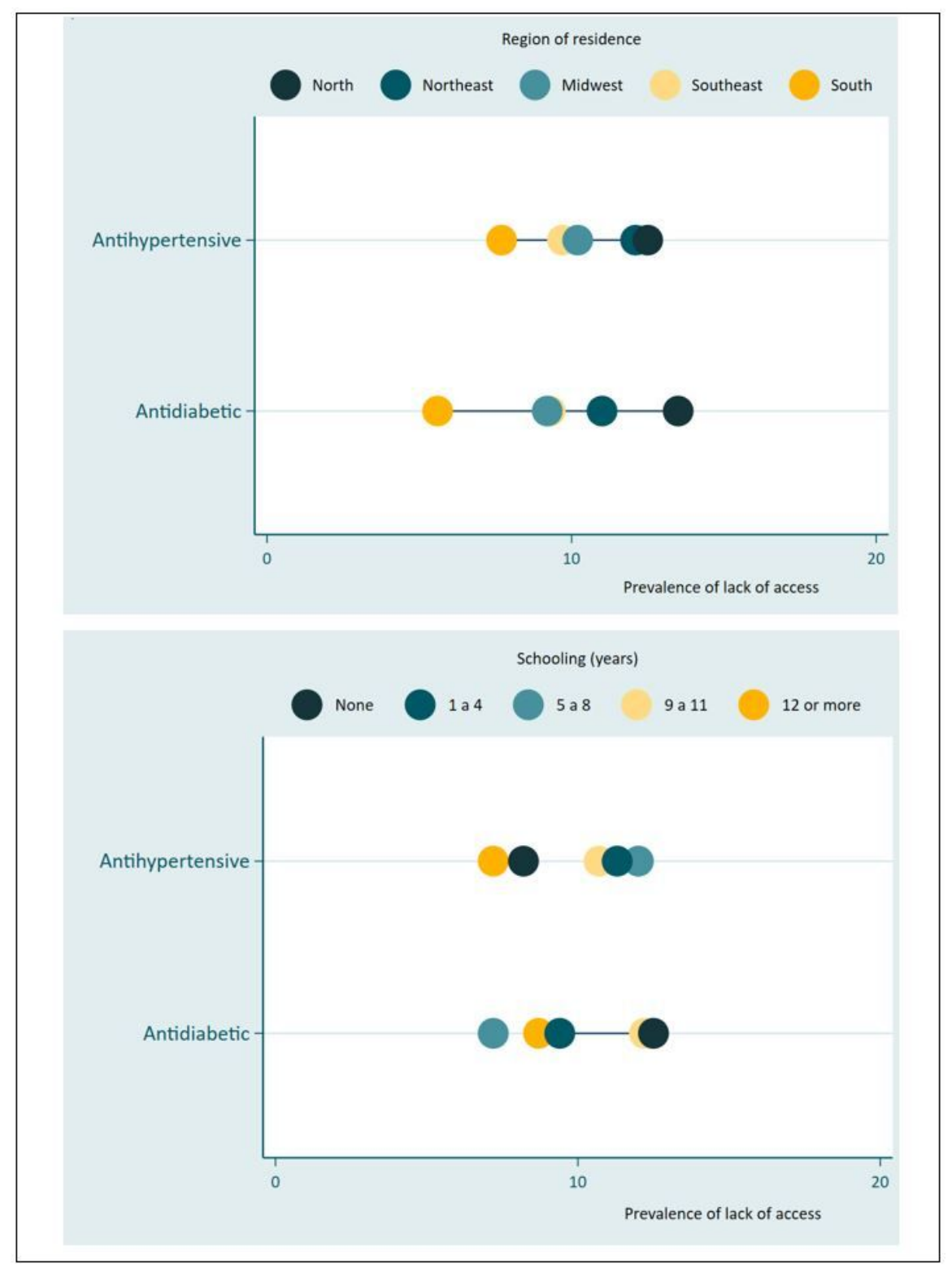

Figure 2

Inequalities in the lack of access to medicines for hypertension and diabetes between adults and the elderly. Vigitel. 2019. 


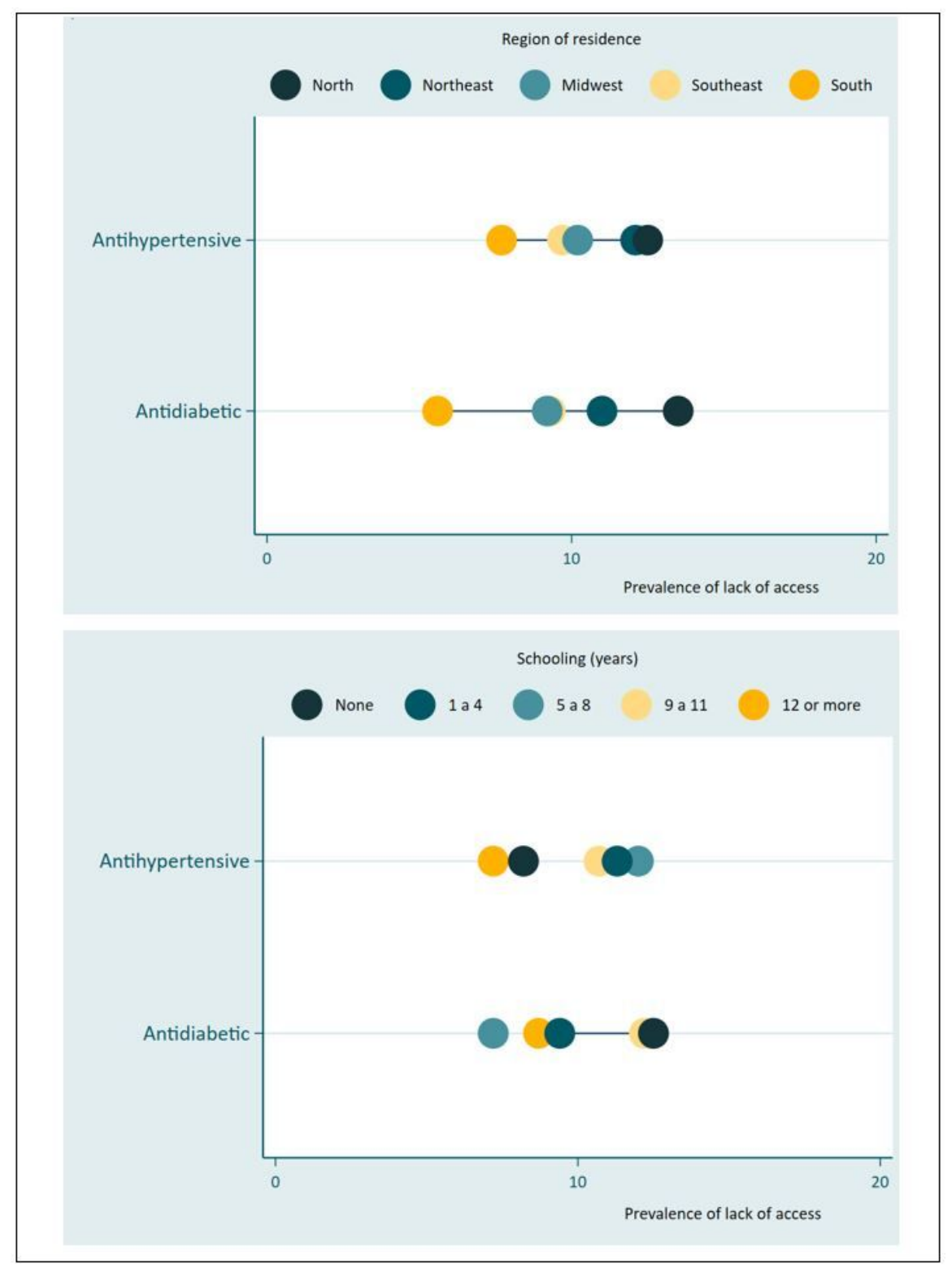

Figure 2

Inequalities in the lack of access to medicines for hypertension and diabetes between adults and the elderly. Vigitel. 2019. 


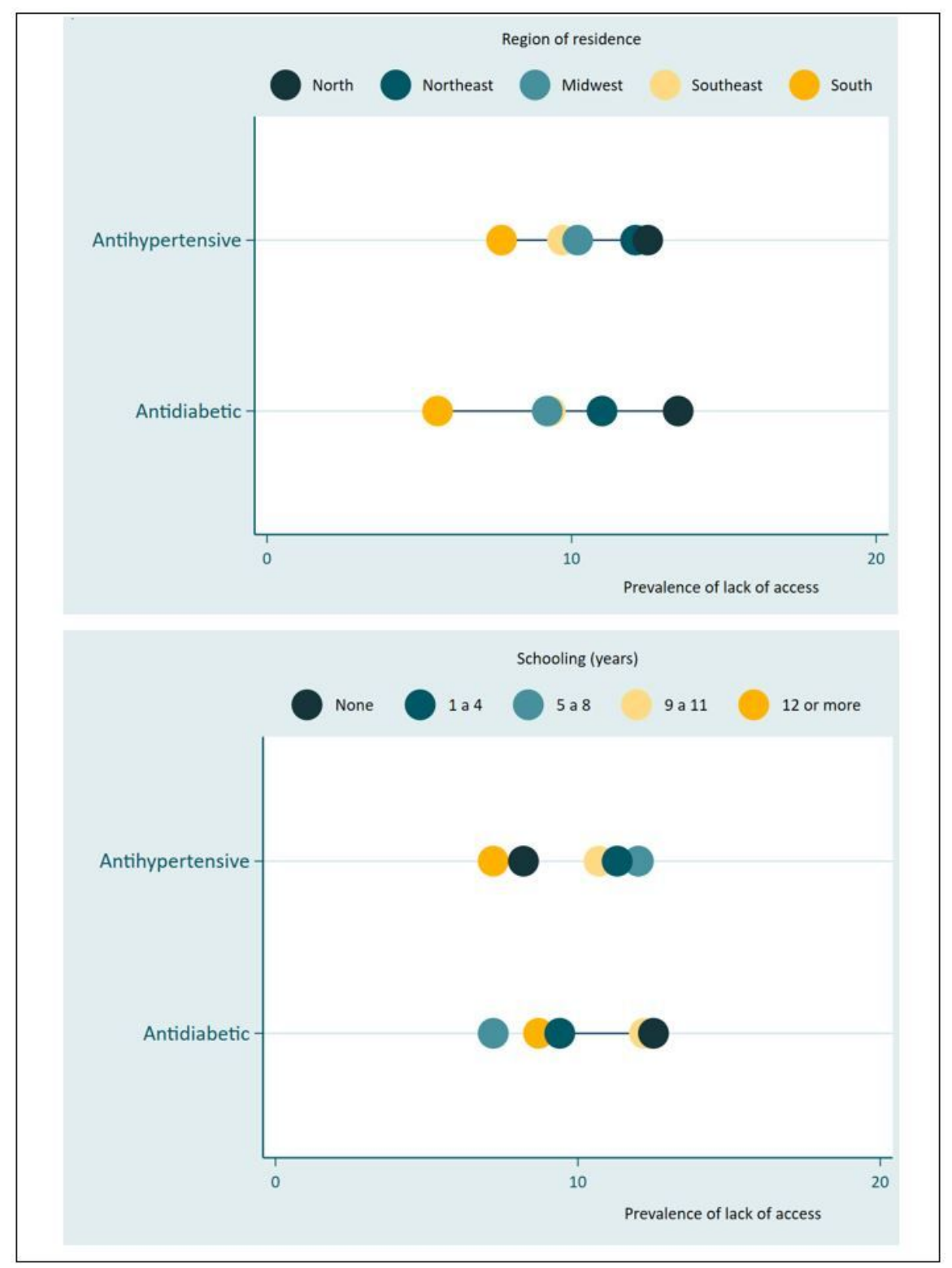

Figure 2

Inequalities in the lack of access to medicines for hypertension and diabetes between adults and the elderly. Vigitel. 2019. 